\title{
Pengaruh Digital Marketing Terhadap Keputusan Pembelian Pada Matahari Department Store Manado Town Square
}

\author{
Fransilia Marsilina Mewoh \\ Johny R. E. Tampi \\ Danny D.S. Mukuan \\ Jurusan Ilmu Administrasi Bisnis, Program Studi Administrasi Bisnis \\ Fakultas Ilmu Sosial dan Politik. Universitas Sam Ratulangi \\ fransiliam@gmail.com
}

\begin{abstract}
The purpose of this study was to determine the effect of digital marketing on purchasing decisions at Matahari Department Store Manado Town Square. The method used in this study is quantitative research methods and instruments used, namely questionnaires measured using a Likert scale. The analysis used in this study is simple linear regression analysis. The number of respondents in this study were 100 respondents consisting of men and women of various ages and occupations. From the results of data analysis obtained the coefficient of determination ( $R$ Square) of 0.194, so that it can be interpreted that E-commerce has a very low influence on purchasing decisions at Matahari Department Store Manado Town Square outlets. The results of the simple linear regression analysis, a positive regression coefficients is obtained so it can be said that the direction of the influence E-Commerce variables on the purchasing decision variable positive.
\end{abstract}

Keywords : Digital Marketing and Purchasing Decision

\section{Pendahuluan}

Pada saat ini digital marketing sangat digemari oleh para pelaku bisnis dalam melakukan kegiatan jual beli. Beralih dari pemasaran tradisional ke pemasaran modern yaitu digital marketing, suatu perusahaan dapat menggunakan digital marketing sebagai media pemasaran dalam meningkatkan volume penjualan baik dalam negeri maupun hingga luar negeri. Salah satu contoh dari digital marketing yaitu E-Commerce. E-Commerce atau Electronic Commerce adalah salah satu bentuk dari pemasaran modern dimana E-
Commerce meng-gunakan internet dalam memasarkan produk, dan melakukan transaksi pembayaran. E-commerce dapat berupa iklan, web ataupun aplikasi.

$$
\text { E-Commerce tidak hanya }
$$
memberikan manfaat terhadap perusahaan saja tetapi juga terhadap masyarakat selaku konsumen. Dilihat dari lifestyle masyarakat di era digital ini maka E-Commerce dapat menjadi alternatif bagi masyarakat selaku konsumen dalam berbelanja ataupun memerlukan jasa seperti transportasi online atau jasa pengiriman barang tanpa memerlukan pertemuan atau negosiasi 
terlebih dahulu, tetapi dapat dilakukan menggunakan perantara berupa smartphone, notebook dan komputer yang tersambung dengan jaringan internet.

Kehadiran E-Commerce sebagai media transaksi modern di Indonesia tentunya memberikan dampak yang sangat menguntungkan bagi banyak pihak seperti konsumen dan produsen. Perkembangan ECommerce di Indonesia semakin pesat dari tahun ke tahun dengan adanya beberapa platform online yang mapan seperti Blibli, Lazada, Shopee dan beberapa platform online lainnya.

PT. Matahari Department store Tbk ("Matahari" atau "Perseroan") merupakan salah satu perusahaan ritel terbesar di Indonesia yang bergerak pada bidang fashion. Tantangan utama Matahari Departemen Store sepanjang tahun yaitu rendahnya konsumsi domestik yang mencapai kurang dari 5\%, tertinggal jauh dari pertumbuhan ekonomi domestik secara keseluruhan. Hal ini menempatkan industri ritel di Indonesia berada di bawah tekanan yang cukup besar, dan penjualan ritel secara keseluruhan hanya tumbuh sebesar $1,2 \%$ dari tahun sebelumnya sehingga sejumlah ritel yang ada di Indonesia memilih untuk menutup kegiatan operasional mereka di tengah-tengah pertanda bahwa konsumen di Indonesia akan mulai lebih banyak menggunakan kegiatan berbelanja melalui jalur online. Di tahun 2017 hingga 2018 Matahari Departemen Store telah menutup empat gerainya yang berlokasi di Jakarta, Lombok dan Medan. Penutupan gerai tersebut dikarenakan kurangnya kontribusi dalam .peningkatan volume penjualan, sehingga Matahari Departemen Store memutuskan untuk menutup empat gerai tersebut.

Berdasarkan dari latar belakang di atas. Maka dari itu saya ingin melakukan penelitian dengan judul yaitu "Pengaruh Digital Marketing Terhadap Keputusan Pembelian Pada Matahari Departemen Store Manado Town Square"

\section{Pemasaran}

Philip dan Keller (2012) dalam buku Wibowo dan Priansa (2017:109) menyatakan bahwa pemasaran adalah seni dan ilmu memilih pasar sasaran dan meraih, mempertahankan, serta menumbuhkan pelanggan baru dengan menciptakan, menghantarkan dan mengkomunikasikan nilai pelanggan yang unggul.

\section{E-Commerce}

Menurut Jony Wong (2010) dalam buku Malau (2017:299) electronic commerce adalah pembelian, penjualan dan pemasaran barang serta jasa melalui sistem elektronik. Terdapat enam indikator dalam 
E-Commerce menurut Hidayat (2008:7), dalam Maulana, Heru dan Riyandi (2015) yaitu :

1. Produk

Terdapat banyak jenis produk yang dapat dijual melalui internet, diantaranya seperti produk fashion, makanan, alat elektronik dan sebagainya.

2. Tempat Menjual Produk

Tempat menjual produk ialah internet yang berarti harus memiliki domain dan hosting.

3. Cara Menerima Pesanan

Banyak cara yang dapat dilakukan untuk menerima pesanan, diantaranya dengan menggunakan e-mail, telephone, sms, chatting maupun aplikasi atau keranjang belanja.

4. Pembayaran

Cara untuk melakukan pembayaran yakni dengan kartu kredit, transfer bank dan juga bisa dengan payment.

5. Metode pengiriman

Pengiriman bisa dilakukan melalui jasa kurir pengantar barang apabila produk yang dibeli berupa barang.

6. Customer Service

Layanan yang diberikan untuk berhubungan langsung dengan perusahaan dan biasanya digunakan untuk menanyakan kejelasan produk atau kesulitan cara pemesanan bahkan melayani keluhan pelanggan.

Secara umum E-Commerce dapat diklasifikasikan menjadi beberapa jenis yaitu sebagai berikut :

1. Business to Business (B2B)

2. Business to Consumer (B2C)

3. Consumer to Consumer $(\mathrm{C} 2 \mathrm{C})$

4. Consumer to Business (B2C)

5. Collaborative Commerce

6. Intra business Commerce

7. Government to Citizens (G2C)

8. Government to Business (G2B)

9. Government to Government (G2G)

10. Mobile Commerce

11. Online to Offline $(\mathrm{O} 2 \mathrm{O})$

\section{Keputusan Pembelian}

Menurut Schiffman dan Kanuk (2010) dalam jurnal Harjati dan Lusia (2014) keputusan adalah seleksi terhadap dua pilihan alternatif atau lebih. Jika mempunyai pilihan antara melakukan pembelian atau tidak, orang itu berada dalam posisi pengambilan keputusan.

\section{Indikator Keputusan Pembelian}

Indikator keputusan pembelian menurut Kotler dan Armstrong (2012) dalam buku Wibowo dan Priansa (2017:300) menjelaskan bahwa keputusan konsumen untuk melakukan pembelian suatu produk meliputi lima indikator yaitu: 
1. Pilihan Produk

Konsumen dapat mengambil keputusan untuk membeli sebuah produk atau menggunakan uangnya untuk tujuan yang lain.

2. Pilihan Merek

Konsumen harus mengambil keputusan tentang merek mana yang akan dibeli. Setiap merek memiliki perbedaanperbedaan tersendiri.

3. Pilihan Penyalur

Konsumen harus mengambil keputusan dimana sebuah produk dibeli.

4. Waktu Pembelian

Konsumen dapat mengambil keputusan tantang kapan ia harus melakukan pembelian.

5. Jumlah Pembelian

Konsumen dapat mengambil keputusan tentang seberapa banyak produk yang akan dibelinya pada suatu saat. Pembelian yang dilakukan mungkin lebih dari satu.

Tahap-tahap proses keputusan pembelian menurut Kotler dan Armstrong (2012) dalam buku Wibowo (2017:312) dan Priansa terdiri dari :

1. Pengenalan Masalah

Keputusan pembelian diawali dengan adanya kebutuhan dan keinginan konsumen, dimana dalam hal ini pelanggan menyadari adanya perbedaan antara keadaan yang sebenarnya dengan keadaan yang diinginkannya.

2. Pencarian Informasi

Setelah konsumen menyadari adanya kebutuhan terhadap produk tertentu, selanjutnya konsumen tersebut akan mencari informasi, baik yang berasal dari pengetahuannya maupun berasal dari luar.

3. Evaluasi Alternatif

Setelah informasi diperoleh konsumen akan mengevaluasi berbagai alternatif pilihan dalam memenuhi kebutuhan tersebut.

4. Keputusan Pembelian

Apabila tidak ada faktor lain yang mengganggu setelah konsumen menentukan pilihan yang telah ditetapkan, maka pembelian yang aktual adalah hasil akhir dari pencarian dan evaluasi yang telah dilakukan

5. Evaluasi Pasca Pembelian

Apabila produk yang dibeli tidak memberikan kepuasan yang diharapkan, maka konsumen akan mengubah sikapnya terhadap merek produk tersebut menjadi sikap negatif, bahkan mungkin akan menolak produk tersebut di kemudian hari.

6. Waktu Pembelian

Pelanggan dapat mengambil keputusan tentang kapan ia harus melakukan pembelian. Masalah ini akan 
menyangkut tersedianya uang untuk membeli sebuah produk.

7. Cara Pembayaran

Pelanggan harus mengambil keputusan tentang metode atau cara pembayaran produk yang dibeli apakah secara tunai atau cicilan.

\section{Metode Penelitian}

Penelitian yang digunakan dalam penelitian ini yaitu penelitian kuantitatif. Populasi dalam penelitian ini yaitu konsumen Matahari yang berbelanja secara langsung pada Gerai Matahari Department Store Manado Town Square yang jumlahnya tidak diketahui sehingga dapat dikategorikan ke dalam populasi tidak terhingga. Untuk menentukan sampel digunakan rumus Rao Purba (2006) dalam Arianto dan Patilaya (2018), sehingga diperoleh sampel sebanyak 100 orang. Teknik pengumpulan data yaitu menggunakan kuesioner dan studi kepustakaan. Instrumen penelitian yang digunakan adalah skala likert dan untuk menguji instrumen penelitian menggunakan uji validitas, uji reliabilitas dan analisis koefisiensi determinasi ( $\mathrm{R} \quad$ Square). Analisis data yaitu menggunakan analisis linear sederhana.

\section{Hasil Penelitian}

a. Uji Validitas
Semua pernyataan yang terdapat dalam variabel E-Commerce (X) yaitu sebanyak 11 pernyataan dikatakan valid, dimana $r$ hitung $>r$ tabel $(0,1945)$ dan semua pernyataan yang terdapat dalam Keputusan Pembelian (Y) yaitu sebanyak 10 pernyataan dikatakan valid, dimana $r$ hitung $>r$ tabel $(0,1945)$, sehingga semua pernyataan yang terdapat dalam variabel ECommerce (X) dan Keputusan Pembelian (Y) dapat digunakan dalam penelitian ini.

\begin{tabular}{ccc}
\hline Variabel & $\begin{array}{c}\text { Cronbach } \\
\text { Alpha }\end{array}$ & Keterangan \\
\hline $\begin{array}{c}\text { E-Commerce } \\
\text { Keputusan } \\
\text { Pembelian }\end{array}$ & 0,682 & Reliable \\
\hline
\end{tabular}

Sumber : Data Olahan 2019

Berdasarkan hasil pada table di atas dapat dilihat bahwa uji reliabilitas dalam perhitungan Cronbach Alpha untuk variabel $\mathrm{X}$ atau E-Commerce mempunyai nilai sebesar 0,682 dan variabel $Y$ atau Keputusan Pembelian mempunyai nilai sebesar 0,712. Hasil pengujian reliabilitas dari variabel $\mathrm{X}$ dan $\mathrm{Y}$ menunjukan bahwa masing-masing variabel memiliki nilai > 0,06 sehingga dapat dikatakan reliabel.

\section{Analisis Koefisiens Correlation Product} Moment (R) dan Koefisiens Determinasi (R Square)

Berdasarkan hasil analisis data dengan menggunakan SPSS 25, maka diketahui nilai koefisien korelasi (R) Sebesar 0,440. Pada tingkat koefisien 
determinasi atau ( $\mathrm{R}$ square) mempunyai nilai sebesar 0,194 atau 19,4\%, angka tersebut dapat diartikan bahwa pengaruh antara Digital Marketing yaitu ECommerce Terhadap Keputusan Pembelian sangat rendah.

\begin{tabular}{cc}
\hline Koefisien Korelasi & Tingkat Hubungan \\
\hline $0,00-0,199$ & Sangat Rendah \\
$0,20-0,399$ & Rendah \\
$0,40-0,599$ & Sedang \\
$0,60-0,699$ & Kuat \\
$0,80-1,000$ & Sangat Kuat \\
\hline
\end{tabular}

Sumber : Sugiyono 2014

\section{Analisis Regresi Linear Sederhana}

Diketahui persamaan regresi sederhana dalam penelitian ini yaitu sebagai berikut :

$$
\mathrm{Y}=18,280+0,429 \mathrm{X}
$$

Berdasarkan hasil uji regresi linear sederhana di atas maka di ketahui nilai konstanta yaitu 18,280 dan koefisiensi regresi $X$ yaitu 0,492 , sehingga setiap penambahan $1 \%$ pada variabel $\mathrm{X}$ maka terjadi kenaikan sebesar 0,429 pada variabel Y. Sehingga dapat di katakana bahwa variabel $\mathrm{X}$ berpengaruh positif terhadap variabel Y.

\section{Pembahasan}

Berdasarkan dari hasil penelitian diketahui bahwa semua pernyataan yang terdapat dalam variabel $\mathrm{X}$ dengan indikator yaitu produk, tempat menjual produk, cara menerima pesanan, pembayaran, metode pengiriman, customer service dan variabel
Y dengan indikator yaitu pilihan produk, pilihan merek, pilihan penyalur, waktu pembelian dan jumlah pembelian dinyatakan valid karena nilai $r$ hitung lebih besar dari $r$ tabel. Jika dilihat pada uji reliabilitas dalam perhitungan Cronbach Alpha untuk variabel $\mathrm{X}$ atau E-Commerce maka hasil pengujian reliabilitas dari variabel $\mathrm{X}$ dan $\mathrm{Y}$ menunjukan bahwa masing-masing variabel dikatakan reliable.

Koefisien regresi tersebut bernilai positif, sehingga dapat dikatakan bahwa arah pengaruh variabel $\mathrm{X}$ terhadap variabel $\mathrm{Y}$ adalah positif.

Koefisien determinasi ( $\mathrm{R}$ Square) memiliki pengaruh yang sangat rendah terhadap keputusan pembelian pada gerai Matahari Department Store Manado Town Square dan terdapat faktor lain yang tidak diteliti seperti faktor kepribadian yang terdapat dalam perilaku konsumen, store atmosphere dan kurangnya pengetahuan konsumen dalam menggunakan aplikasi ataupun situs web. Faktor kepribadian dapat diklasifikasikan dalam beberapa karakter yaitu diantaranya yaitu usia dan siklus hidup, pekerjaan dan status ekonomi, kepribadian dan konsep diri serta gaya hidup dan nilai. Store atmosphere dapat mempengaruhi keputusan konsumen dimana dengan desain lingkungan toko yang menarik, melakukan komunikasi visual, pencahayaan, warna dan music. 
Kepribadian dan gaya hidup setiap orang berbeda-beda, kebanyakan konsumen yang ada di kota Manado lebih tertarik dengan belanja ke gerai Matahari secara langsung di mana dengan pergi ke gerai Matahari secara langsung konsumen dapat memastikan kualitas produk yang ingin dibeli dan juga dapat secara langsung merasakan store atmosphere yang ada secara langsung.

Tidak hanya faktor kepribadian dan store atmosphere saja tetapi kurangnya pengetahuan konsumen dalam menggunakan aplikasi dan situs web dalam berbelanja juga dapat memberikan pengaruh terhadap keputusan konsumen dimana sebagian konsumen yang mengetahui bagaimana cara berbelanja dengan menggunakan aplikasi ataupun situs web merupakan sesuatu yang dapat mempermudah kegiatan berbelanja mereka atau dapat membuat kegiatan berbelanja menjadi lebih praktis, tetapi bagi konsumen yang kurang mengetahui bagaimana cara menggunakan aplikasi ataupun situs web dalam berbelanja dapat menjadikan kegiatan berbelanja menjadi tidak praktis atau konsumen dapat merasa bahwa prosedur yang ada dalam berbelanja secara online itu membuat mereka kurang nyaman. Sehingga dapat memberikan pengaruh juga terhadap keputusan untuk lebih memilih berbelaja secara langsung pada gerai Matahari dibandingkan dengan menggunakan E-Commerce yang berupa aplikasi ataupun situs web.

\section{Kesimpulan}

Terdapat pengaruh antara variabel ECommerce (X) dan variabel keputusan pembelian (Y) pada Matahari Departemen Store Manado Town Square, jika dilihat dari tabel koefisien termasuk ke dalam golongan yang sangat rendah. Terdapat variabel atau faktor lain yang memiliki pengaruh yang lebih besar dalam keputusan pembelian yang tidak diteliti oleh penulis dalam penelitian ini seperti faktor kepribadian yang terdiri dari beberapa aspek, store atmosphere dan kurangnya pengetahuan konsumen terhadap bagaimana cara menggunakan aplikasi ataupun situs web dalam melakukan proses berbelanja secara online

Berdasarkan hasil dari analisis regresi linear sederhana maka diperoleh nilai koefisien regresi yang positif, sehingga dapat dikatakan bahwa arah pengaruh variabel E-Commerce terhadap variabel keputusan pembelian yaitu positif.

\section{Saran}

Setelah diperoleh pengaruh antara variabel E-Commerce dan variabel keputusan pembelian pada Matahari Departemen Store Manado Town Square 
yang sangat rendah diharapkan peneliti selanjutnya akan meneliti tentang faktor atau variabel lainnya yang mempunyai hubungan yang lebih besar / tinggi terhdap keputusan pembelian sehingga dapat digunakan sebagai dalah satu acuan dikemudian hari.

Diharapkan kepada perusahaan yaitu PT. Matahari Department Store agar lebih mengetahui apa saja yang menjadi kebutuhan konsumen dan juga lebih inovasi dalam meningkatkan design dari produknya sehingga dapat meningkatkan volume penjualan perusahaan.

\section{Daftar Pustaka}

Malau. Herman, 2017. Teori dan Aplikasi Pemasaran Era Tradisional Sampai Era Modernisasi Global. Bandung : ALFABETA

Wibowo, Adi Lili dan Donni, Juni Priansa. 2017. Manajemen Komunikasi dan Pemasaran. Bandung: ALFABETA

Maulana, Mifta, Shabur. Heru, Susilo dan Riyadi (2015) "Implementasi ECommerce Sebagai Media Penjualan Online (Studi Kasus Pada Toko Pasbrik Kota Malang)". Jurnal Administrasi Bisnis (JAB). No. 1. Vol. 29

Wenas. R.S. Jackson (2013) "Kualitas Produk, Harga, Promosi dan Kualitas Pelayanan Pengaruhnya Terhadap Keputusan Pembelian Spring Bed Comfort”. Jurnal EMBA. No. 4. Vol. 1.
Harjati, Lily dan Lusia, Olivia, Sabu G (2014) "Pengaruh Presepsi Kualitas Produk Terhadap Keputusan Pembelian The Body Shop". Jurnal WIDYA Ekonomika. No. 1. Vol. 1

Aianto, Nurmin dan Eramaya, Patilaya (2018) "Pengaruh Kualitas Produk dan Kelengkapan Produk Terhadap Keputusan Pembelian Produk Salt n Pepper Pada PT Mitra Busana Sentosa Bintaro". Jurnal Kreatif : Pemasaran. No. 2. Vol. 6 